\title{
Gener påvirker beintetthet
}

Islandske forskningsresultater øker kunnskapen om genene bak ulikheter i beintetthet.

Beintetthet er den beste prediktoren for beinbrudd forårsaket av beinskjørhet og brukes som en referanse i beskrivelse av osteoporose. Osteoporoseutvikling påvirkes både av arv og miljø, og det er ved genomvide assosiasjonsstudier identifisert gener som påvirker risikoen. I slike studier undersøkes hele genomet for å identifisere gener eller polymorfismer som påvirker sykdomsrisiko.

Islandske forskere har nå identifisert flere gener og polymorfismer som påvirker beintetthet ved å utføre slike studier på 6865 islendinger og 8510 kontrollpersoner (1).

- Resultatene er svært interessante fordi de bekrefter tidligere funn, påviser sterkere sammenhenger og identifiserer nye gener og genvarianter assosiert med beintetthet og med risiko for lavenergibrudd, sier gynekolog og postdoktor Åshild Bjørnerem ved Universitetet i Tromsø. En begrensning i studien er at de påviste assosiasjonene er svake og at identifiserte gener kun forklarer $4 \%$ av totalvariasjonen $i$ beintetthet $i$ hofte og ryggvirvel.

- Identifisering av gener og polymorfismer i gener som for eksempel koder for osteoprotegerin (OPG), RANK (receptor activator of nuclear factor $\kappa \mathrm{B})$, østrogen-

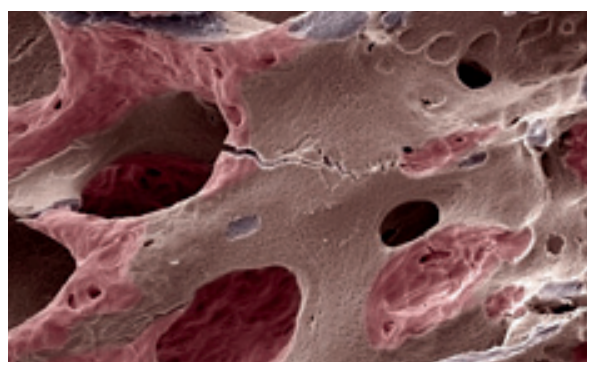

Osteoporotisk beinstruktur, skanningelektronmikroskopi. Foto Science Photo Library/GV-Press/ NordicPhotos

reseptor og sclerostin er et viktig bidrag til økt innsikt i beinremodelleringen, prosessen som er avgjørende for etablering av beinmasse $\mathrm{i}$ ung alder og beintap ved $ø$ kende alder. Forhåpentligvis kan genetiske markører bidra til tidlig og bedre identifisering av personer med høy bruddrisiko i fremtiden, og for mer målrettet behandling av dem som trenger det mest, sier Bjørnerem.

\section{Åslaug Helland}

aslaug.helland@gmail.com

Tidsskriftet

\section{Litteratur}

1. Styrkarsdottir U, Halldorsson BV, Gretarsdottir S et al. New sequence variants associated with bone mineral density. Nat Genet 2009; 41: 15-7.

\section{siRNA - fremtidens terapi ved ovarialkreft?}

\section{Musestudier gir lovende resultater med bruk av siRNA i behandling av ovarialkreft.}

Ovarialkreft har høy dødelighet. Cellegift har ofte god effekt primært, men kreftcellene utvikler etter hvert resistens mot behandlingen. Nå har forskere undersøkt effektiviteten av lipidoidformulert siRNA mot proteinet claudin-3 i tre musemodeller (1).

Proteinet claudin-3 er overuttrykt i over $90 \%$ av ovarialsvulster og er viktig for kreftcellenes evne til å overleve og spre seg. siRNA er små inhiberende RNA-molekyler som kan slå av uttrykket av bestemte proteiner. Forskerne undersøkte siRNA-molekyler som slo av uttrykket av claudin-3 i musemodeller. Det lipidliknende medikamentet ble injisert intraperitonealt på musene og resulterte i signifikant redusert tumorvekst. I tillegg så man at ascitesproduksjonen ble redusert. Det ble ikke sett toksisitet hos musene.

- I behandlingen av eggstokkreft har vi sannsynligvis nådd så langt vi kan med bruken av tradisjonell kjemoterapi, sier overlege Gunnar Kristensen ved Oslo universitetssykehus, Radiumhospitalet. Det er behov for helt nye medikamenttyper, og videre fremskritt vil være knyttet til bruk av såkalt målrettet behandling, der man griper inn i biologiske prosesser som tumorcellene er avhengige av.

- Det er allerede blitt, og vil fortsatt bli, foretatt en rekke kliniske studier for å vurdere effekten av denne type behandling. Bruken av siRNA i dyremodeller virker såpass lovende at det vil være naturlig å fortsette denne forskningen, slik at man på sikt også kan teste det hos pasienter med eggstokkreft, sier Kristensen.

\footnotetext{
Åslaug Helland

aslaug.helland@gmail.com

Tidsskriftet

Litteratur

1. Huang $Y H, B a o Y$, Peng $W$ et al. Claudin-3 gene silencing with siRNA suppresses ovarian tumor ( 2009; 106: 3426-30.
}

\section{Gåten merkelceller}

Merkelceller i huden har vært kjent i over hundre år, men funksjonen har vært uklar og omdiskutert. Det har vært postulert at disse cellene står for kodingen av sensorisk stimulering som gjør at deres afferente nerver kan oppfatte ulik grad av berøring. Amerikanske forskere har nå testet denne hypotesen i en musemodell (Science 2009; 324: 1580-2).

Det ble ikke utviklet merkelceller i områder på dyrene som hadde en delesjon av en transkripsjonsfaktor uttrykt i merkelceller. Hud/nervepreparasjoner fra disse områdene manglet fullstendig den karakteristiske nevrofysiologiske responsen som normalt medieres av et kompleks av merkelceller og nervefibre. Dette bekrefter disse cellenes viktige rolle i det somatosensoriske systemet.

\section{Myopi hos skolebarn}

Myopi er relativt vanlig blant skolebarn. Arbeid som krever mye akkomodasjon, slik som lesing, kan kanskje øke risikoen for å utvikle myopi. Resultatene fra en studie av kinesiske skolebarn kan imidlertid ikke bekrefte denne hypotesen (Arch Ophthalmol 2009; 127: 769-75).

Nesten 1300 barn gjennomgikk grundig synsundersøkelse og svarte på spørreskjema om leseavstand og annen type nærarbeid. Det var ingen sammenheng mellom hvor mye nærarbeid de drev med og graden av myopi.

\section{Platehemmere kan gi cerebrale mikroblødninger}

Rotterdam-studien, en populasjonsbasert studie av nesten 8000 personer over 55 år, er en av verdens største innen helse hos eldre. Nå har en stor undergruppe av deltakerne gjennomgått en spesiell type MRundersøkelse - T2-gradient-ekko-MRI som identifiserer mikroblødninger i hjernevevet (Arch Neurol 2009; 66: 714-20).

Resultatene viser at bruk av acetylsalisylsyre sannsynligvis øker risikoen for slike mikroblødninger. I tillegg så det ut til at lokalisasjonene av blødningene avhang av hvilken type acetylsalisylsyre pasienten brukte. Personer som ble regelmessig behandlet med antikoagulerende medikamenter som warfarin, hadde derimot ingen $ø k t$ forekomst av mikroblødninger. 